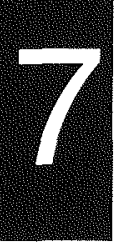

\title{
Common property and regional sovereignty: relations between aboriginal peoples and the Crown in Canada
}

\section{Peter J. Usher}

In a world where even nation-states have declining power and authority in the face of global markets, international trade agreements, and harmonised laws and regulations, what does sovereignty mean at the subnational level? And what is the connection between common property and sovereignty at the subnational level? What challenges and opportunities confront minority indigenous populations in these contemporary circumstances? The situation of aboriginal peoples in Canada provides distinctive perspectives on these questions. In our country, new understandings are being reached, new arrangements forged and implemented, but also, new difficulties and challenges are emerging.

\section{Recognition and disregard of aboriginal property and sovereignty}

Aboriginal peoples not only used and occupied their territories, they also regulated access to their lands and resources by outsiders and access within them by members. Aboriginal property in lands and resources existed in at least three forms: as a discrete physical space, as a set of relations among the landholding group, and a right in the eyes of others. Property relations are, of course, rules about who has rights 
to what, and how they can exercise those rights. They are thus a fundamental element of sovereignty or self-government.

In 1763, a Royal Proclamation declared British recognition of aboriginal title and rights in what is now Canada, although the specific content of this recognition, and of Canada's obligations in respect of it, have been much debated politically and in the courts. At the least, we can say that the Proclamation recognised title insofar as it established a lawful process for obtaining aboriginal lands by negotiation and treaty, and that until this process had occurred, aboriginals were to remain unmolested in their use of their land and under the protection of the Crown. It also, by implication at least, recognised aboriginal sovereignty insofar as it acknowledged treaty-making partners capable of acting politically on behalf of landholding groups.

How the recognition of aboriginal title and rights evolved in practice in Canada is a sorry story, which can only be highlighted here. ${ }^{1}$ Canadian courts have from time to time acknowledged the existence of aboriginal title, but characterised it merely as usufructuary, or more recently as sui generis, which gives the appearance of recognition while at the same time emptying it of practical content and effect. So it came about that in the eyes of the law, aboriginal rights in land and resources (when acknowledged) were not exclusive, provided neither defence nor remedy against nuisance, trespass, or expropriation, and did not bind or encumber third parties granted competing land or resource rights by the Crown.

The treaty-making process, as it evolved for over a century and a half after the Royal Proclamation, was intended by the colonial government and later Canada to clear the way for settlement and development. According to the English language versions as published by Canada, these treaties constituted surrenders of vast territories in exchange for limited hunting rights on unoccupied Crown lands, cash payments for supplies and personal annuities, and reserve lands which typically amounted to no more than one per cent of the ceded territory.

What Indians regarded as their own lands on which they would be self-governing, Canada cast as Dominion lands 'set apart for Indians' (Indian Act, s.18(1)), temporarily it hoped, as places of confinement and assimilation. The effect was to set aside property for Indian use, but not to recognise Indian relations of property, and certainly not their communal nature or its implications.

Further, the division of powers between the Dominion Government and the provinces at Confederation (British North America Act 1867) 
was considered to have fully allocated sovereignty in Canada, leaving no room for the exercise of aboriginal sovereignty, perhaps least of all with respect to the disposition and management of land, water, and natural resources.

Canada's unilateral intepretation of the treaties, its Constitution, and the Indian Act, combined to deny completely aboriginal sovereignty and self-government. Two hundred years after the Royal Proclamation, Canada was firmly committed to an assimilationist policy, and regarded the treaties as quaint anachronisms that could and should be disregarded if they stood in the way of the public good (which government regarded as also the aboriginal good). The idea that aboriginal rights might persist and have substance outside of the treaty areas (the substantial part of Canada not yet included in the treaty-making process when it ended in 1930) was simply not considered.

\section{Reclaiming property and sovereignty-two directions}

When the movement to reclaim aboriginal and treaty rights gathered momentum in the 1970s, there was a range of approaches based in no small measure on aboriginal peoples' specific historical experience. In the southern, settled areas of Canada, the focus was on the development of self-government on the reserves. There was little interest in (or hope for) the 99 per cent of land that had been lost. Other than exercising hunting and fishing rights, there was little assertion of territorial rights on settled and alienated land. In the far north, where Inuit and Indians had experienced little impact from settlement and development, and where the use of land and water continued largely uninterrupted, the assertion of rights was over the entire territory. In the mid-north, where although use of off-reserve lands continued, there had been progressive encroachment and restriction by development activities, government regulations, and settlers, the assertion of rights was also territorially extensive, but there was much emphasis on seeking remedies for past damages. In the northern treaty areas, Indians saw these incursions and damages as a long history of treaty violations, and signs of a treaty partner no longer to be trusted. ${ }^{2}$

The effect was that in the south, and to a large extent in the midnorth, Indians pursued autonomy and sovereignty, even if over limited territories, whereas in the far north, Inuit and to some extent Indians sought to retain a range of rights over their entire territories 
but were more prepared to enter into relations of partnership and cooperation. On the one hand, coexistence in separate spheres, on the other, cooperation and participation. This is necessarily an oversimplification, but it provides some insight into different outcomes in the north and south of Canada, and to the successes and limitations of comprehensive claims agreements.

\section{Modern comprehensive claims agreements}

As a result of certain political and judicial events in the early 1970s, Canada acknowledged that there were outstanding aboriginal interests in unceded land and that it was prepared to negotiate modern treaties on the basis of them (Chrétien 1973). The Office of Native Claims was given a mandate to negotiate, in exchange for extinguishment, certain land and resource benefits, title to a limited quantum of lands (including subsurface rights to a small proportion thereof), preferential or exclusive access to fish and wildlife, and limited participation in the management of these resources, and monetary compensation. Other benefits not related to lands and resources were also offered, but the overall package did not include self-government (Canada 1981). ${ }^{3}$

The new policy included some significant departures from the old treaty pattern, with respect to lands, resources, and environment. For our purposes, these were

- the land quantum to be negotiated was far greater than what was provided for (although not necessarily greater than what Indian signatories had understood they would get) in the numbered treaties, although much of this would consist of surface title only

- the lands selected would be held in freehold directly by an aboriginal corporate entity, rather than by Canada for the benefit of aboriginal people

- cash compensation for lost lands would be substantial, and would be paid to an aboriginal corporate entity rather than to individuals

- hunting and fishing rights would be exclusive or preferential, and to some extent compensable

- aboriginal people would have some involvement in wildlife and environmental management. 
The land, resource, and environment regimes established under the comprehensive claims process provide some measure of protection of land and resources from the adverse effects of development, and also for mitigation and compensation where such effects do occur. These modern treaties thus address problems perhaps not foreseen, and certainly not explicitly dealt with, in the historic treaties. They do so by acknowledging and balancing both aboriginal and non-aboriginal interests throughout the traditional territory. Some incidents of aboriginal title are formally recognised on all lands (except the very limited areas in freehold tenure), more in some categories of land than in others, yet nowhere are they complete.

The modern treaties also provide an institutional framework for the continuing negotiation and mutual accommodation of aboriginal and non-aboriginal interests in the governance of land, resources, and environment. They provide for aboriginal involvement in the management of the entire territory, but not their exclusive governance or sovereignty over any of it. This is a vision of integration and participation, of a continuing and evolving relationship between partners, rather than of separation and coexistence (Usher 1997).

What follows is a description of what happens when aboriginal rights have been recognised and codified, and must then be exercised in a situation where the presence, interests, and rights of others, both within the territory or 'settlement region' and outside of it, must be acknowledged and negotiated. In most of the cases referred to, the primary economic orientation of the aboriginal population is a mixed, subsistence-based economy, based on local-level subsistence and commercial exploitation of fisheries and wildlife, employment, and transfer payments. Industrial employment, where it occurs, is in the minerals, oil and gas sectors. There is no agriculture, and with few exceptions, no forestry or pastoralism.

\section{The provisions for co-management}

The principle of co-management is perhaps the most innovative and yet least understood elements of the modern treaties. It applies not only to wildlife and fisheries - the so-called 'traditional' resourcesbut also to environmental protection and regulation, and land use planning. ${ }^{4}$

The basic structure of co-management consists of boards or committees responsible for specific management areas such as 
wildlife, fisheries, impact screening and review, land use planning, and water management. Members are usually appointed in equal numbers by governments and beneficiary organisations.

Geographically, the jurisdiction of these boards extends to all of the lands within the settlement area, whether in aboriginal, Crown, or private tenure. The boards are technically advisory to the appropriate minister, and do not replace existing government agencies. They are intended to guide the overall direction of policy, and have a range of powers from making binding decisions, approvals, advice, and research direction. Here, for example, is how the role of the Nunavut Wildlife Management Board (NWMB) is described in the Nunavut Land Claims Agreement

Recognizing that Government retains ultimate responsibility for wildlife management, the NWMB shall be the main instrument of wildlife management in the Nunavut Settlement Area and the main regulator of access to wildlife and have the primary responsibility in relation thereto (Department of Indian Affairs and Northern

Development 1993:5.2.33).

Comprehensive claims have not been the only basis for the development of co-management. Some important and enduring examples pre-date many of the claims, and limited forms of comanagement have been implemented outside of the comprehensive claims areas. However, the claims-based regimes are the strongest and most enduring, not least because they are constitutionally protected under section 35 of the Constitution Act, 1982. They cannot be unilaterally disbanded or ignored by Canada, or by its provinces and territories.

At the time that co-management options were first seriously negotiated in comprehensive claims, the alternative was continued and more comprehensive devolution to the territorial governments. Instead, at least a nominal form of power-sharing was the outcome. Governments were not entirely averse to this compromise, and certainly preferred it to aboriginal self-government with respect to lands and resources. The Supreme Court's Sparrow decision ${ }^{5}$ also provided an impetus for co-management-consultation has become one of the key tests of constitutionally acceptable conservation limitations on aboriginal harvesting rights. The co-management boards provide a useful 'single window' for governments to deal with specific resource issues. With respect to wildlife and fisheries, comanagement is a means of enlisting harvester cooperation to ensure 
conservation, as an alternative to deploying draconian and expensive (but often unsuccessful) enforcement measures.

From an aboriginal perspective, co-management establishes a principle completely ignored (if not explicitly rejected) in Canada's interpretation of the historic treaties. It is that aboriginal people retain, as a result of claims settlements, some rights not only of use but of management, and in effect governance, that apply on all Crown lands and in more limited respects on private lands, throughout the traditional territory or 'settlement region'. The modern treaties create an institutional basis for cooperation and coexistence, for problem solving and for the harmonising of mutual interests, with respect to all lands and resources. This is quite different from the traditional denial of all collective aboriginal rights save residual hunting and fishing rights outside of reserve lands. In most cases where it has been implemented it has been a counterweight and buffer to the progressive encroachment and restriction on the use of customary lands and resources, to harvest disruption, and to the loss of social and cultural as well as economic values.

On the other hand, the emerging pattern is not one of selfdetermination or autonomy. It would certainly appear, based on the structures and mandates established by the comprehensive claims, that the state management system has been retained. The general pattern is that allocation and licensing is delegated to the boards and the local harvester organisations, but management for conservation is reserved to governments, with the boards having only an advisory role (although in practice their decisions are rarely if ever varied or rejected). The boards are technically institutions of public government, on which aboriginals are guaranteed equal representation with governments. The co-management boards thus do not replace existing resource management agencies-at most they provide guidance to them. This is less than what many, and perhaps most, harvesters wanted.

\section{Co-management in practice}

Co-management has been implemented in Canada in a variety of situations since the early 1980s. Some of these have been claims-based, others have been cobbled together as ad hoc solutions to land and resource management crises. In both cases, there have been notable achievements in conservation through self-regulation, community 
land use and conservation planning, co-management of national parks, impact screening and review, negotiating interjurisdictional agreements on resource access and management, and in problem solving generally.

Most co-management boards, and especially the claims-based ones, are bilateral arrangements between aboriginal peoples and governments, and hence do not necessarily include all interested parties. That is probably one reason that boards have often been able to achieve consensus over basic management objectives, for example, management for subsistence in the case of the Beverly-Qamanirjuaq Caribou Management Board (BQCMB) (Usher 1993). As well, the boards are mandated to implement the objectives of the claims agreements, which in the case of the Inuvialuit Final Agreement (IFA), for example, clearly link aboriginal harvesting rights with conservation (Staples 1997). However potentially competing interests such as resident sport hunters or the guiding industry are not directly represented on the boards (although governments may choose in some cases to nominate such individuals as their representatives). While this has not been a significant problem in the Northwest Territories (NWT), it accounts for some of the differences in board structures in the Yukon, and for some of the resistance to co-management in the provincial North (see, for example, Brooke 1997, Larcombe 1997, and Penn 1997). Where third party interests are well established, multi-party approaches at the local level as in the Shuswap pilot project in British Columbia (Pinkerton, Moore and Fortier 1997) or the Barriere Lake agreement in Quebec (Notzke 1997) are likely to be essential elements of success.

Some observers have suggested that co-management offers a potential bridge between indigenous and state systems of knowledge and management (Usher 1987, Osherenko 1988). The record of achievement in this regard is mixed, but co-management has provided a forum or venue for continuing negotiation over matters crucial to both aboriginal peoples and governments. Whether the integration or bridging of traditional and scientific knowledge is always an appropriate or achievable objective of co-management remains to be seen. One substantial achievement in most cases has been agreement on research objectives and methods, and the sharing of data. The scientific research on which management is based is undertaken with the knowledge and consent of harvesters (for example the BQCMB) and often the research priorities, design, and budgets are effectively directed by the co-management board and, for example in the IFA, the 
Inuvialuit Game Council. In the NWT, the boards have their own secretariats with technical as well as adminis-trative capacity, hence aboriginal representatives have access to expertise outside of the line management agencies. The composition of boards is quite similar in all of the agreements, in particular the provision for equality of representation. What is crucial to the outcome is who in practice appoints (or which set of interests appoints) the members, the effective mandate and accountability of the members, and the actual operating procedures. These factors can either serve to paper over and suppress real differences, or give proper recognition and expression of them.

The experience of most boards shows that consensus often builds over time among board members, and the agencies they represent. As already mentioned, co-management board decisions are rarely if ever varied or rejected by the ministers they advise. However this is not sufficient, at least on the government side, to bind all those whose actions (or inaction) may have an impact on management. For example, support for IFA implementation on the part of local or regional government agencies is not necessarily sustained at headquarters, and there are some government departments not directly represented on the boards who are indifferent at best, or hostile at worst, to board recommendations (Staples 1997).

The costs of implementation and of effective participation are proving to be substantial: consistent attention, expert research and advice, and extensive travel are required. The final agreements themselves do not specify what human and financial resources are required to implement their provisions. That has been a matter for subsequent negotiations, and has sometimes proved the source of fundamental disagreement or dissatisfaction between parties and beneficiaries.

There has been a range of responses to co-management initiatives by aboriginal groups. Some have found that their co-management arrangements suit their needs well, and that they can use them to their advantage. Others find co-management at least acceptable in as much as it is a significant improvement over the former closed-door system of management. Still others have no desire to co-manage resources with outsiders but seek exclusive management authority within a limited geographical area. In assessing co-management, it is necessary to consider the diversity of circumstances surrounding its negotiation and implementation.

There is some evidence that co-management is more likely to be preferred where migratory or transboundary populations are 
involved. In such cases, governments and users from several jurisdictions are brought together in a single forum. Perhaps not surprisingly, those groups (such as the Inuvialuit) most dependent on migratory species such as caribou, waterfowl, whales, and polar bears, are co-management's most convinced advocates. They regard it as the key to resource conservation, and to social and political stability respecting resource harvesting, despite some day-to-day problems and frustrations. By contrast, the Anishinabe of northwestern Ontario historically relied on fish and wildlife resources with quite restricted ranges, or even non-mobile resources such as wild rice. These resources could be and were managed exclusively within a limited area, hence the benefits of co-management are less obvious (Chapeskie 1995). The differences in environmental circumstances between these two aboriginal peoples is compounded by both ideology and historical experience-certainly, in the case of the Anishinabe, of a much more thorough and devastating history of progressive encroachment and restriction (Usher et al. 1992).

There is no one answer to the question of whether co-management has proven an advantage more to governments or to beneficiaries, or for that matter, whether it has been to the equal advantage of both. Nor is it clear whether it is better to have single, comprehensive boards dealing with large areas (such as the NWMB which covers about one-fifth of Canada), or several more specialised boards (as in the case of the IFA boards), or local, community-based boards in which non-aboriginal residents participate (such as the Renewable Resource Councils in the Yukon).

Nonetheless, three features of the claims-based regimes appear to be critical to the successful implementation of co-management (Usher 1995). First, the co-management structures, and their mandate, objectives, and mode of operation, are themselves negotiated. This is very different from inviting people to sit on a body whose mandate and operations have already been determined unilaterally. Second, aboriginal members of claims-based boards are politically accountable appointees of one of the parties to an agreement, not simply 'stakeholders' or 'users', as is the case on the ad hoc boards. In some of the latter type of boards, (including the well-known BQCMB), only governments are signatories to the management agreement. The rights and powers of users are specified but not guaranteed; they are granted by governments and do not constitute a recognition of existing rights. Third, only the claims-based arrangements are permanent. The ad hoc 
arrangements are in place only for a limited period, subject to discretionary renewal and funding by government.

Co-management may work best when the parties have similar interests in and objectives regarding the resources in question. Ideally each contributes its own knowledge to achieve a shared objective of sustainability. If objectives are not shared, then knowledge may not be shared and communication will be impaired. This problem is likely to increase as the number of parties to co-management increases.

\section{Benefits of co-management}

The key elements of the modern treaties regarding land tenure, resource access, and co-management provide for enforceable rights of property and governance. The resulting security of tenure, access, and management regime provide essential conditions for local economic growth and social development. Typically, where co-management has been implemented, local and regional economies can be characterised as mixed, subsistence-based economies. They are certainly not traditional in the sense of being antiquated or undeveloped, but northern aboriginal communities have quite distinctive social, cultural, and economic objectives and needs that are not fully addressed by the standard models of economic development. The security achieved by the claims agreements is important not so much for capital investment by lending institutions, as for the investment in social capital by aboriginal people themselves in the form of the skills, knowledge, and values required for harvesting. For the most part, such communities are quite prepared to work with outside resource development interests if they can maximise the economic benefits, minimise environmental and social damages, and retain their renewable-resource based harvesting economies for both subsistence and commercial purposes.

Under the modern agreements, not only are aboriginal priorities with respect to harvesting guaranteed, but co-management arrangements provide the tools of cooperative governance necessary to secure both harvesting and marketing in a national and international context. Aboriginal peoples have been involved in international markets for centuries, and have no interest in returning to some imaginary pristine autarky. Yet this market access is now under unprecedented assault from an urban public increasingly divorced from, and sometimes hostile to, the realities of the sustainable use of living resources. 
Through implementing co-management regimes, aboriginal people not only continue harvesting but are learning new and quite different skills: negotiating, marketing, finding out how the larger world works and how to operate in it, directing research, setting priorities, and in general defending and advancing their interests in a positive way. In doing so they reinforce their collective sense of the role and importance of their common property arrangements and subsistence systems, and their culturally-based knowledge, values, and skills that are required to make these things work in contemporary conditions. Scientists and administrators also learn how to expand the knowledge inputs required to operationalise modern systems of conservation and development to include traditional environmental knowledge and understanding.

Another feature of the modern agreements is the provision for negotiating impact benefit agreements where third parties seek to exercise their resource rights on aboriginal lands (where aboriginal entities hold surface but not subsurface titles, or where prior Crown grants survive). These agreements may include such matters as project mitigation, environmental monitoring, compensation for loss of use or direct damages to the environment as well as to property, all of which require continuing cooperative arrangements between the parties and which may also be characterised as a form of voluntary comanagement.

Such arrangements are increasingly (although by no means universally) accepted by large resource companies as good business sense in that they provide for certainty with respect to development and investment which the state, on its own, is unable to fully guarantee except by the most draconian and publicly unacceptable methods.

One feature of co-management is that it brings people together in a way that they can learn to respect each other and understand their interests, priorities, and perspectives. When this happens, people are more likely to make accommodations, and more likely to see the process as mutually beneficial rather than as a zero-sum game.

The process of co-management is costly, but it is also necessary to look at avoided costs. Direct actions, disruptions, and court challenges are also costly. In the historic treaty areas where these issues remain unresolved, when aboriginal people want to do things they believe they have a right to do, they act. When charged and prosecuted, they defend themselves in court on the basis of their aboriginal or treaty 
rights. Some of these cases have significantly enlarged both the legal content and the public understanding of these rights, but there have also been some significant losses. Any major case that eventually goes all the way up to the Supreme Court is likely to take years and cost millions of dollars, all of which creates uncertainty for both customary common property holders and potential investors.

On balance, experience suggests that contemporary comanagement arrangements between aboriginal peoples and Canadian governments, as well as third parties, meet the tests of conservation, equity, and efficiency, and therefore provide the conditions for sustainable development. Experience also suggests that the principles of co-management can be applied to other spheres, ranging from the international (such as the recently established Arctic Council and its role in environmental protection, and the standing it provides to aboriginal political organisations). They can also be applied to other resource management issues at the regional level such as nonrenewable resource development and to program delivery relating to such matters as health and education.

There is a new way of doing business in the Canadian North, and many are recognising its useful and beneficial aspects. Nothing is permanent, however, and the maintenance of effective comanagement requires ongoing vigilance and the solution of new problems.

\section{Challenges for co-management}

In the long run, co-management arrangements and agreements will only be as good as the parties are prepared to make them. There is a special requirement for vigilance on the part of the weaker party, which is invariably the aboriginal party. Comprehensive claims agreements are protected under section 35 of the Constitution Act, 1982, and their provisions are paramount over any other federal, provincial, or territorial legislation which may be inconsistent with them. Nonetheless, governments must constantly be reminded of these facts, especially when drafting new legislation. Although there are arbitration provisions under the claims agreements, there are no enforceable penalties for federal non-compliance.

It is up to the aboriginal party to ensure that the rest of the world complies with their agreements. The costs and complications of effectively administering such large tracts of land bring both problems 
and opportunities. The slowness of actual demarcation on the ground has been a problem where development pressures are great, as in the case of forestry adjacent to southern Cree lands in Quebec (Penn 1997). Overly prescriptive regimes which cannot evolve and adapt to changing conditions will ultimately fail to address key problems, and the parties will eventually bypass them (Brooke 1997, Wilkinson and Vincelli 1997).

Although the courts in recent years have led the way in reinterpreting the historic treaty provisions in a more liberal and expansive fashion, this cannot be relied on in the case of the modern treaties. Canadian courts already regard these as more equitable contracts in which the aboriginal parties had full capacity to negotiate agreements and to understand the consequences of what they had agreed to.

There has to be political will to implement agreements. The opportunities for slippage in the first few critical years of implementation, when operational patterns are getting established, are substantial. It is the aboriginal party that must seize the initiative and ensure that implementation is effective.

Co-management thus clearly requires mutual respect and equitable political relations. But it also requires substantial resources to implement. Without adequate resources, there can be no effective participation in co-management regimes, which requires (among other things) travel, translation, access to information, and continuity of representation. The seats may be there, but that is not much help if people have neither the money nor the capacity to fill them, or if for these and other reasons they are discouraged from filling them.

The pattern of modern comprehensive claims settlements was set in the 1980s when governments still spent money freely, and took an activist role in land and resource management. Periodic renegotiation of implementation funding (which after initial one-time implementation tasks relates largely to the co-management system) will get tougher. Disputes may now more likely occur not over differing legal interpretations of substantive obligations, but what expenditures are required to meet these obligations. New measures and practices of management effectiveness and efficiency will be required. How to trade off higher costs of doing business, and of conducting research, against reduced enforcement costs, crisis avoidance, and enhanced sustainability? Co-management can become a victim of its own success: to the extent that it reduces conflict, it becomes less noticeable in the eyes of those who ultimately allocate the funds. 
Another area future disagreement may be the role of government in land and environmental management. In an era of downsizing and privatisation, what are the implications of government withdrawal? It is hard to continue to implement an agreement when one partner gets up from the table and walks away. Problems may also emerge in the maintenance of the essential character of common property, with the creation of corporate and state-like entities under comprehensive claims, although it is too early to assess actual developments.

Modern treaties have secured a legal base for aboriginal property. The collective title is held by corporate entities, with certain important limits with respect to transfer or alienation to non-beneficiaries. Is there a risk that in the long run collective property can be converted to private tenure? I believe that aboriginal property systems are in principle recognisable by the common law system even if they are different, but it will be a challenge to characterise them in this way without undermining them. There is also the question of whether, under conditions of scarcity or economic difficulty, limited entry and tradeable resource rights could emerge even in the face of fundamental values of universal access. Customary property relations do evolve and change as new conditions arise.

Boundary issues may also be problematic. Traditional use and occupancy are the basis of aboriginal claims in law and policy. What are the implications of using this concept to define the territorial limits of jurisdiction of 'state-like' institutions? The modern treaty process is creating subnational (or sub-territorial) political and administrative units, with mandates and responsibilities organised along state or corporate lines. This is very far from the recognition and entrenchment of traditional aboriginal forms of socio-territorial organisation. By reifying what were formerly fluid and imprecise boundaries according to contemporary requirements of state administration (even if an aboriginal government is in charge), there is a probability of separation of title and use over time, contrary to aboriginal principles and traditions. Some evidence of the social difficulties this poses with particular respect to registered traplines have been reported in the Cree area of Quebec (McDonnell and La Rusic 1987) and the Yukon. The emergence of 'overlap' and boundary disputes among neighbouring claimant groups is also an indication of the effect of creating state-like jurisdictional boundaries.

Finally, there is the question of how far the model can spread. The most successful examples of implementation come, not by coincidence, 
from the territorial North. The conditions conducive to success there have not held to the same degree in the provincial North, where third parties are more involved, and more numerous and varied resident interests and property rights are at stake. Because aboriginal people are constitutionally a federal responsibility, provincial governments have historically represented settler interests, and still do. Crown land disposition and resource management are provincial responsibilities, south of the 60th parallel, and there is much more resistance to comanagement which is seen, perhaps especially in Quebec, as an attack on provincial sovereignty and territorial integrity. Land claims agreements are meeting increasing resistance in the provinces from a growing sector of the public that attacks them as 'race-based privilege', as a form of apartheid, and as contrary to democratic and egalitarian principles.

\section{Conclusion}

Where aboriginal groups have embraced co-management, they have embarked on a path of partnership and cooperation with government, sometimes the private sector, and in effect with other Canadian citizens. There is an alternative, but it implies the maintenance of distance, isolation, and to some extent social if not economic autarky.

While aboriginal and historic treaty rights are protected under the constitution, in the absence of negotiated agreements it is still left to the courts to determine what they are. This is a slow, uncertain, and uneven process, and it is possible that the high-water mark has already been reached in Canada, and the tide is ebbing. Waiting to negotiate until formal recognition of certain principles occurs, or until certain processes are in place, is also risky. True equality cannot be achieved by declaration alone, and it cannot be wished into existence. Imbalances of demographic and economic power are facts of life in Canada and will continue to be such for a very long time. None of this is to deny the tremendous symbolic importance of formal acts of recognition, but rights, once acknowleged, have to be exercised in a real world where neither property nor sovereignty are unbounded.

What Canadian aboriginal peoples have achieved through the comprehensive claims process and through the implementation of comanagement regimes is far from perfect. In comparison to the situation of indigenous peoples in other countries, however, much has been achieved by at least some Canadian aboriginal peoples to secure rights 
of tenure, access, and management of their lands, resources, and environment.

Co-management is not autonomy or self-determination. But it is much more than consultation or participation. Property and management rights have not simply been defined and defended by the law of the state, but also by agreements which were negotiated, not unilaterally imposed, and which are constitutionally protected. Co-management is not a separatist or isolationist vision, but one of cooperation and sharing. These are values not to be dismissed in today's world. There will always be hostility and resistance from some quarters. There will always be a need to form alliances to protect one's interests, and co-management can help people to do that. The struggle continues, but on new and higher ground.

\section{Notes}

1. This section is a condensation of Usher, Tough, and Galois 1992. For a useful legal interpretation of the process of conversion of Indian lands to Crown lands, see Slattery 1987. For a more expanded discussion, see Canada 1996, especially vol. 2, ch. 2, 'Treaties', and vol. 2, ch. 4, 'Lands and Resources'.

2. Canada also acknowledged limited responsibility for dealing with past failures to honour its treaty obligations under the Specific Claims Policy (Canada 1982), which applied to the treaty areas. However, policy implementation has been unilaterally and narrowly determined by Canada. Loss of use of off-reserve resources, subsistence or non-market resource values, and resource management issues, are all excluded from consideration.

3. Developments in aboriginal self-government are beyond the scope of this paper, but have also taken two directions. One is the creation of public government in territories in which aboriginal peoples are the majority (Nunavut and Nunavik). The other has been to assert an 'inherent right of self-government' whose content would be negotiable or justiciable (which was a part of the unratified Constitutional proposals of 1992). This discussion focuses entirely on the regimes established by comprehensive claims and related processes and does not address the constitutional debates.

4. This and the following sections are based on the results of the Land, Resource, and Environment Regimes Project undertaken for the Royal Commission on Aboriginal Peoples, consisting of eight case studies of contemporary co-management regimes established by the comprehensive claims process and other circumstances, and a synthetic analysis (Usher 1997). The entire set of reports is available on CD-ROM (Royal Commission on Aboriginal Peoples 1997).

5. R. v. Sparrow, [1990] 1 S.C.R. 1075. 


\section{References}

Brooke, L.F., 1997. 'The James Bay and Northern Quebec Agreement: experiences of the Nunavik Inuit with wildlife management,' [CDROM], in Royal Commission on Aboriginal Peoples, For Seven Generations: an information legacy of the Royal Commision for Aboriginal Peoples, Libraxus, Ottawa.

Canada, 1981. In All Fairness: a native claims policy, Supply and Services Canada, Ottawa.

- 1982. Outstanding Business: a native claims policy, Supply and Services Canada, Ottawa.

- 1996. Report of the Royal Commission on Aboriginal Peoples, Canada Communication Group, Ottawa.

Chapeskie, A., 1997. 'Land, Landscape, Culturescape: Aboriginal Relations to Land and the Co-management of Natural Resources,' [CD-ROM], in Royal Commission on Aboriginal Peoples, For Seven Generations: an information legacy of the Royal Commision for Aboriginal Peoples, Libraxus, Ottawa.

Chrétien, J., 8 August 1973. Statement on Indian and Inuit Claims, Department of Indian Affairs and Northern Development, Ottawa.

Larcombe, P.M., 1997. 'The Northern Flood Agreement: implementation of land, resource and environmental regimes in a treaty area,' [CD-ROM], in Royal Commission on Aboriginal Peoples, For Seven Generations: an information legacy of the Royal Commision for Aboriginal Peoples, Libraxus, Ottawa.

McDonnell, R.F., and I.E. La Rusic, October 1987. Forestry Operations and Hunting Organization Among Waswanipi Cree, Unpublished report prepared for Cree Regional Authority, HUSO Services Inc., Montreal.

Notzke, C., 1995. 'The Barriere Lake Trilateral Agreement,' [CD-ROM], in Royal Commission on Aboriginal Peoples, For Seven Generations: an information legacy of the Royal Commision for Aboriginal Peoples, Libraxus, Ottawa.

Department of Indian Affairs and Northern Development, 1993.

Nunavut Land Claims Agreement, Department of Indian Affairs and Northern Development, Ottawa.

Osherenko, G., 1988. Sharing Power with Native Users: co-management regimes for Arctic wildlife, Canadian Arctic Resources Committee, Ottawa. 
Penn, A., 1997. 'The James Bay and Northern Quebec Agreement: natural resources, public lands, and the implementation of a native land claim settlement,' [CD-ROM], in Royal Commission on Aboriginal Peoples, For Seven Generations: an information legacy of the Royal Commision for Aboriginal Peoples, Libraxus, Ottawa.

Pinkerton, E.W., D. Moore, and F. Fortier, 1997. 'A Model for First Nation Leadership in Multi-Party Stewardship of Watersheds and their Fisheries,' [CD-ROM], in Royal Commission on Aboriginal Peoples, For Seven Generations: an information legacy of the Royal Commision for Aboriginal Peoples, Libraxus, Ottawa.

Royal Commission on Aboriginal Peoples, 1997. For Seven Generations: an information legacy of the Royal Commision for Aboriginal Peoples [CD-ROM], Libraxus, Ottawa.

Slattery, B., 1987. 'Understanding aboriginal rights,' Canadian Bar Review 66:726-83.

Staples, W.L., 1997. 'The Inuvialuit Final Agreement: implementation of its land, resource and environmental regimes, [CD-ROM], in Royal Commission on Aboriginal Peoples, For Seven Generations: an information legacy of the Royal Commision for Aboriginal Peoples, Libraxus, Ottawa.

Usher, P.J., 1987. 'Indigenous management systems and the conservation of wildlife in the Canadian North,' Alternatives 14(1):3-9.

, 1993. 'The Beverly-Qamanirjuaq Caribou Management Board: an experience in co-management,' in J.T. Inglis (ed.), Traditional Ecological Knowledge, Concepts and Cases, International Program on Traditional Ecological Knowledge and International Development Research Centre, Ottawa:111-20.

, 1995. Co-management of natural resources: some aspects of the Canadian experience, in D.L. Peterson and D.R. Johnson (ed.), Human Ecology and Climate Change: people and resources in the Far North, Taylor and Francis, Washington DC:197-206.

1997. 'Contemporary Aboriginal Land, Resource, and Environment Regimes: origins, problems and prospects,' [CDROM], in Royal Commission on Aboriginal Peoples, For Seven Generations: an information legacy of the Royal Commision for Aboriginal Peoples, Libraxus, Ottawa.

Usher, P.J., P. Cobb, M. Loney, and G. Spafford, 1992. Hydro-electric Development and the English River Anishinabe: Ontario Hydro's Past record and present approaches to treaty and aboriginal rights, 
Social Impact Assessment, and Mitigation and Compensation, report prepared for Nishnawbe-Aski Nation, Grand Council Treaty 3, and Teme-Augama Anishnabai, Ottawa, unpublished.

Usher, P.J., F.J. Tough, and R.M. Galois, 1992. 'Reclaiming the land: aboriginal title, treaty rights and land claims in Canada,' Applied Geography 12(2):109-132.

Wilkinson, P.F., and M. Vincelli, 1995. "The James Bay and Northern Quebec Agreement: an evaluation of the implementation of its environmental regimes,' [CD-ROM], in Royal Commission on Aboriginal Peoples, For Seven Generations: an information legacy of the Royal Commision for Aboriginal Peoples, Libraxus, Ottawa. 